International Journal of Agriculture, Environment and Bioresearch

Vol. 4, No. 05; 2019

ISSN: $2456-8643$

\title{
FARMERS' KNOWLEDGE, ATTITUDE AND BEHAVIOR IN RESPONSE TO GOODS AND SERVICES TAX (GST)
}

\author{
Nor Hidayah Hassim and Norsida Man \\ http://doi.org/10.35410/IJAEB.2019.4450
}

University Putra Malaysia, Faculty of Agriculture,43400 Serdang, Selangor, Malaysia

\begin{abstract}
Malaysia had officially replaced Sales and Services Tax (SST) to Goods and Services Tax (GST) since 1st April 2015. The changes lead to many responses but mostly are negative due to the lack of knowledge and information on GST. Agriculture output such as rice, vegetables, fruits, meats and eggs were categorized as zero-rated supply which they are free from GST. However, maintenances on the farm such as fertilizers, herbicides, ruminant feed, planting tools and others are in GST implementation. This shown the unbalance conditions by farmers as they are harvesting products which are free from GST but still pay GST in preparing them. Are the farmers suffered from such conditions? Thus, this study was undertaken to investigate on the farmers' behavior in response to GST. Primary data were collected using structured questionnaire via face to face interview with 400 respondents from Kelantan, Kedah, Johor and Selangor. Majority of the respondents did not accept GST implementation in Malaysia (45.5\%) followed by $33.5 \%$ were uncertain and $21 \%$ were accepted. Most of the respondents did not receive any information about GST information (64\%). The perception level of respondents towards knowledge, attitude and behavior on GST implementation were moderate $\mathrm{M}=2.358$, $\mathrm{M}=2.913$ and $\mathrm{M}=2.818$ respectively. The results showed by the three levels are mostly negative perceptions. The farmers should be provided with a clearer tax information, trainings and finance management for their survival on any new tax levied
\end{abstract}

Keywords: Goods and Services Tax (GST), Knowledge, Attitude, Behavior.

\section{INTRODUCTION}

Agriculture is entitled as the third important economic activity in Malaysia after services and manufacturing sector which contributed 8.2\% to Gross Domestic Product (GDP) (DOSM, 2015) [4]. The geographic position of Malaysia which located on the middle of the earth equator provides the country with masses biodiversity of flora and fauna and poses as the sources to agriculture productions. Variation of agriculture productions in Malaysia was mainly begin from palm oil and rubber industries. Then, the sector derived gradually to progressive expansion of various crops, livestock and fisheries productions. From global economic view, agriculture stands as a vital sector which involves on national revenue and export earnings by supplying food including raw products (WTO, 2017) [16].

Total contribution from agriculture industry (including palm oil) showed a slight GDP fall from 
7.3 percent in 2012 to 7.1 percent in 2013. However, agriculture subsectors (fisheries, livestock and other agriculture) have achieved national GDP rose from 3.17 percent in 2012 to 3.22 percent in 2013. The performance of each agriculture food subsectors can be observed clearly through the breakdowns of the GDP contributions. From fisheries subsector, it showed GDP decline from 1.05 percent in 2012 to 1.02 percent in 2013. Meanwhile, the contribution of livestock industry to GDP rose from 0.85 percent in 2012 to 0.88 percent in 2013 . For crops subsectors, the GDP also achieved increment from 1.26 percent in 2012 to 1.3 percent in 2013 (ETP, 2014) [5]. In conjunction, these shows that agriculture sector involves in various contributions to the economy through its multi-functional roles and inter-sectorial bonds.

Agriculture is a global well-known sector that growth sturdy by its multiple subsectors, allowing numerous taxation access. Taxation is a collective tool for the government's taxing and spending strategies. The spending strategies are involving the expenditures of government which mainly emphasize on development of infrastructure, trade and industry, including agriculture. Government has taxed agricultural producers to generate revenues to finance government expenditure, transfer resources (agricultural surplus) to nonagricultural sectors, promote efficiency and diversification of agricultural production and redistribute incomes within the agriculture sector (Khan, 2000) [10]. These effected the regional and rural communities, including farmers in agriculture sector who are depending on an effective and decent tax system that derived tax revenue for economic growth and socio viability.

On 1st April 2015, Sales and Services Tax (SST) had replaced to Goods and Services Tax (GST) but it changed back to SST by the new government, right after they won the election in May 2018. The concept of Goods and Services Tax (GST) was first introduced by a French tax official in 1950's. To date, there are numerous strong economic countries in the world that have practiced this form of taxation including Australia, European Union and Asian countries likes Singapore and China. However, GST was implemented not only less than three years as a fiscal policy in Malaysia showing a drastic refusal from the citizens to the tax system. This study will show in narrower perspective from farmers in agriculture sector during the GST implementation.

The general objective of the study is to study level of respondents' behavior in respond to GST implementation. Meanwhile, the two specific objectives of the study are;

1. To examine the socio demographic profile of respondents.

2. To determine level of knowledge, attitude, subjective norms and behavior towards GST implementation.

\section{LITERATURE REVIEW}

\subsection{Definition of Goods and Services Tax}

GST is a broad-based consumption tax which covers all transactions including imported goods and services except for the goods and services that are classified as zero-rated supply and exempt supply which will be exempted by the Government (Fatt, 2006) [6]. The tax is charged on every supply of taxable goods and services at all levels in the supply chain in the process of production, manufacturing, wholesale and retail. The tax is paid by customers when they purchase goods and services by claiming back form RMCD (Alappatt, 2014) [1]. 
The goal of sustainable Goods and Services Tax is seen as a transformation of Tax system for restructuring the system to make it fairer, efficient and transparent. This nature of GST would help combat the tax leakages and non-compliance. It affects all consumers equally from every level of society regardless of where and how their income is derived. In other word, it affects consumers across the board including the poor and needy. According to Ayob (1994) farmers were the poorest society among community in developing countries [2]. He stated that the poverty of farmers is hardly discard although agriculture sector had been part of economic activity since independence.

Despite the aim of GST, there are factors that need to be taken account in suitability of any tax as part of the policy. Firstly, it is important that the tax levied emphasizes collection cost effectiveness. The complexity of the tax system and degree of taxpayers' acceptance are also the factors that should be consider. Those three factors are the measurements required stated by Smith (1994) for a success of new tax system implementation [14].

\subsection{Goods and Services in Agriculture}

During the least than 3 years of GST implementation, the government and its crew are still in their way to spread out the information of GST in order to combat confusion among people. Sales and contracts are made almost every day and some of these transactions required people to pay the GST. It is an issue if people are still unaware or confuse with the tax system of GST and become worst when people ignore and boycott not to pay the tax. The focus here are to know either farmers are well prepared with the understanding about the procedures, chances, opportunity, and effects in participating themselves in GST. A research carried out by Imam (2015), knowledge has positive and significant effect on tax amenability [8]. A deeper and wider understanding on taxation knowledge will have positive influence by the farmers.

By following the Order 2014, Zero Rated Supplies such as vegetables, rice, fresh spices and fresh potatoes is exceptional from implementation of GST. Meanwhile, other agriculture products such as fertilizers, pesticides, agriculture maintenance equipment and others, those have not been stated in Order 2014 are implemented with 6\% GST (RMCD, 2014) [13]. Basically, most of the farmers need to buy the implemented GST agriculture products for their farm requirement progress. Therefore, they will have no optional to not involve in paying the tax and at the same time there will be no tax for their sales. The matter of how they behave to this situation are important in order to survive and sustain in agriculture sector.

During April 2015 until May 2018, the taxation replacement (SST to GST) has nevertheless emerged effects throughout the nation by economically and socially in agriculture sector. In addition, clearly stated by Jaffer et. al. (2006), modification in tax regulations, monetary services, price level and subsidies can alter significantly the farming profit [9]. Former Agriculture and Agro-based Industry Minister, Datuk Seri Ismail Sabri Yaakob stated that there is slight increase in agricultural products and equipment due to the levied tax. Those are good evidences that the new changes of tax regulations from SST to GST may influence farmers' 
intuitional risk to the farmers and lead to the flexibility of farmers to sustain in agriculture sector.

\section{Methodology}

The primary data collected directly from the questionnaire filled up by the 400 number of farmers as respondents for the study. The survey questions designed according to the objectives of the study. The respondents are mainly from four regions of Malaysia which is Kelantan, Kedah, Johor and Selangor where most of them has high farmers community who their main occupation and income are from agriculture sector. The surveys questions structured into several parts such as demographic characteristic, farm profile, acceptance on GST implementation and level of respondents' knowledge, attitude and behaviour on GST implementation. Descriptive analysis was used to analyse the data which include the percentage and frequency. Frequency analysis was done to obtain information such as gender, age, education level, year of experience in farming, farm area, income of farmers and level of knowledge, attitude and behaviour of respondents on GST implementation.

\section{RESUlT AND DisCUSSION}

The primary data collected directly from the questionnaire filled up by the 400 number of farmers as respondents for the study. The survey questions designed according to the objectives of the study. The respondents are mainly from four regions of Malaysia which is Kelantan, Kedah, Johor and Selangor where most of them has high farmers community who their main occupation and income are from agriculture sector. The surveys questions structured into several parts such as demographic characteristic, farm profile, acceptance on GST implementation and level of respondents' knowledge, attitude and behavior on GST implementation. Descriptive analysis was used to analyses the data which include the percentage and frequency. Frequency analysis was done to obtain information such as gender, age, education level, year of experience in farming, farm area, income of farmers and level of knowledge, attitude and behavior of respondents on GST implementation.

\subsection{Demographic of Respondents}

Table 1: Demographics of the Respondents

\begin{tabular}{|c|c|c|c|}
\hline Variables & Parameter & Frequency & (\%) \\
\hline \multirow{2}{*}{ Gender } & Male & 310 & 77.5 \\
\cline { 2 - 4 } & Female & 90 & 22.5 \\
\hline \multirow{3}{*}{ Age } & $<25$ & 13 & 3.3 \\
\cline { 2 - 4 } & $26-35$ & 68 & 17.0 \\
\cline { 2 - 4 } & $36-45$ & 67 & 16.8 \\
\hline
\end{tabular}


International Journal of Agriculture, Environment and Bioresearch

Vol. 4, No. 05; 2019

ISSN: $2456-8643$

\begin{tabular}{|c|c|c|c|}
\hline & $46-55$ & 110 & 27.5 \\
\hline & $>56$ & 142 & 35.5 \\
\hline \multirow{4}{*}{ Education level } & No education & 91 & 22.8 \\
\hline & Primary & 85 & 21.3 \\
\hline & Secondary & 180 & 45.0 \\
\hline & Higher education & 44 & 11.0 \\
\hline \multirow{7}{*}{$\begin{array}{l}\text { Year of } \\
\text { experience in } \\
\text { farming }\end{array}$} & $1-10$ years & 176 & 44.0 \\
\hline & 11-20 years & 67 & 16.8 \\
\hline & $21-30$ years & 94 & 23.5 \\
\hline & $31-40$ years & 25 & 6.3 \\
\hline & $41-50$ years & 27 & 6.8 \\
\hline & $51-60$ years & 6 & 1.5 \\
\hline & $>60$ years & 5 & 1.3 \\
\hline \multirow{4}{*}{ Farm area } & $<1$ acre & 24 & 6.0 \\
\hline & $1-5$ acres & 122 & 30.5 \\
\hline & 6-10 acres & 223 & 55.8 \\
\hline & $>10$ acres & 31 & 7.8 \\
\hline \multirow{6}{*}{ Income } & $<$ RM1000 & 49 & 12.3 \\
\hline & RM1001-RM2000 & 114 & 28.5 \\
\hline & RM2001-RM3000 & 99 & 24.8 \\
\hline & RM3001-RM4001 & 47 & 11.8 \\
\hline & RM4001-RM5000 & 17 & 4.3 \\
\hline & $>$ RM5000 & 74 & 18.3 \\
\hline
\end{tabular}


In this study, a higher distribution of gender is male representing $77.5 \%$. Both men and women contribute significantly to agricultural production yet, their access to these agricultural resources differ. Despite the contribution of women to agriculture, it is evident that they do not have much access and control over agricultural resources as men. Women are lower by status in household and community resulting limitation in bargaining power and decision making (Meinzen-Dick et al., 2011) [11]. Women are mostly disowned to work on field regarding this matter.

In terms of age, majority of the respondents are more than 56 years old representing $35.5 \%$. Base on DOSM (2017), the highest working aged is 15 to 64 years old [4]. Due to low agricultural profitability, young people are not interested in agriculture and shift towards SME and industrial sectors, so most of elder people involves in farming activities. Most of the respondents had an education at secondary school level representing $45.0 \%$ of the total sample. In terms of working experience in farming, $44.0 \%$ of the respondents have been working between 1 to 10 years. 55.8\% of respondents own farm area 6 to 10 acres. As for their income per month, it shows that majority of them earn between RM1001-RM2000 representing 28.5\%. Husin \& Abdullah (2012) stated that age of trees, advanced age of settlers and non-increasing land size effect income of farmers [7]. This represents why most of respondents are low income earners.

\subsection{Respondents' Acceptance}

Table 2 below showed the frequency and percentage of respondents' acceptability on GST. Most of the respondents rejected GST as the highest answered by respondents are No. The frequency of not accepted GST was 182 which represented $45.5 \%$ from 400 respondents. Then, about 134 respondents were not certain in accepting GST carried out the percentage of $33.5 \%$. The lowest showed that 84 respondents agree to accept GST which represent by $21 \%$ in total.

Table 2: Farmers' Acceptance on GST

\begin{tabular}{|c|c|c|}
\hline $\begin{array}{c}\text { GST } \\
\text { acceptability }\end{array}$ & Frequency & $(\%)$ \\
\hline Yes & 84 & 21.0 \\
\hline Uncertain & 134 & 33.5 \\
\hline No & 182 & 45.5 \\
\hline
\end{tabular}

\subsection{Level of}

Knowledge on GST Implementation

Table 3a represented respondents' knowledge on GST. The statements "I know agricultural inputs for the needs of my farm are subjected to GST" shows the highest mean 4.21. Meanwhile statement "I know who to contact to get more information about GST" showed the lowest mean 2.90 .

Table 3a: Respondents' Knowledge on GST implementation $(n=400)$

\begin{tabular}{|c|c|c|c|c|}
\hline No & Knowledge on GST & Level & Mean & SD \\
\hline 1 & I know the effects of GST on my agricultural & Moderate & 3.02 & 1.290 \\
\hline
\end{tabular}




\begin{tabular}{|c|c|c|c|c|}
\hline & activity & & \\
\hline 2 & $\begin{array}{c}\text { I know I do not have to charge GST to buyers who } \\
\text { bought my farm yield }\end{array}$ & Moderate & 3.05 & 1.378 \\
\hline 3 & $\begin{array}{c}\text { I know agricultural inputs for the needs of my } \\
\text { farm are subjected to GST }\end{array}$ & High & 4.21 & 0.869 \\
\hline 4 & $\begin{array}{c}\text { I know how to plan my plantation management } \\
\text { when the cost of input goods increased }\end{array}$ & High & 3.74 & 1.106 \\
\hline 5 & $\begin{array}{c}\text { I know the government provides assistance to } \\
\text { reduce the burden on farmers }\end{array}$ & Moderate & 3.43 & 1.323 \\
\hline 6 & $\begin{array}{c}\text { I know authorities who distribute information } \\
\text { about GST }\end{array}$ & Moderate & 2.90 & 1.286 \\
\hline & Total average mean & Moderate & 3.392 & \\
\hline
\end{tabular}

Score: 1 = strongly disagree; 2 = disagree; 3 = Neutral; 4 = Agree; 5 = Strongly Agree

Table 3b: Knowledge Perception Level (n=400)

\begin{tabular}{|c|c|c|}
\hline Level & Mean & SD \\
\cline { 1 - 1 } High (3.67-5.0) & \multirow{2}{*}{2.358} & \\
\cline { 1 - 1 } Moderate (2.34-3.66) & 0.645 \\
\cline { 1 - 1 } Low (1-2.33) & & \\
\hline
\end{tabular}

Table $3 \mathrm{~b}$ showed moderate level of respondents' knowledge with the overall mean 2.358. The results show a barrier to the respondents to acknowledge more GST information, but they did not being expose to the various authorities who play the roles in giving GST information. Nurlis (2015) claimed that, service tax authorities have positive and significant relationship taxpayer performances at the Tax Office in Jabodetabek and Bandung area [12]. The study highlighted a suggestion that the better the service tax authorities, the tax compliance rate will be higher.

\subsection{Level of Attitude in Response to GST Implementation}

The respondents' attitude in response to GST is shown in Table 4a which showing the highest mean with the statement "I feel pleasure if the officer can give more information about the GST to farmers" giving the mean of 4.43. Meanwhile the least mean 3.85 from statement, "I still use the same farm input amount despite the price rose by GST". 
Table 4a: Respondents' Attitude in Response to GST $(n=400)$

\begin{tabular}{|c|c|c|c|c|}
\hline No & Attitude on GST & Level & Mean & SD \\
\hline 1 & $\begin{array}{c}\text { I still use the same farm input amount } \\
\text { despite the price rose by GST. }\end{array}$ & High & 3.85 & 1.083 \\
\hline 2 & $\begin{array}{c}\text { I still manage my farm well even farming } \\
\text { input prices increased. }\end{array}$ & High & 4.29 & 0.706 \\
\hline 3 & $\begin{array}{c}\text { I am sure to make my own decisions in } \\
\text { managing the usage of agricultural inputs. }\end{array}$ & High & 4.24 & 0.724 \\
\hline 4 & $\begin{array}{c}\text { I never give up if the tax burdened me in } \\
\text { managing the activities of the farm. }\end{array}$ & High & 4.30 & 0.735 \\
\hline 5 & $\begin{array}{c}\text { I had been prepared if the GST makes my } \\
\text { farming activities declined. }\end{array}$ & High & 4.07 & 0.957 \\
\hline 6 & $\begin{array}{c}\text { I feel pleasure if the officer can give more } \\
\text { information about the GST to farmers. }\end{array}$ & High & 4.43 & 0.672 \\
\hline & Total average mean & 4.197 & \\
\hline
\end{tabular}

Score: 1 = strongly disagree $; 2$ = disagree; 3 = Neutral; 4 = Agree; 5 = Strongly Agree

Table 4b: Attitude Perception Level $(n=400)$

\begin{tabular}{|c|c|c|}
\hline Level & Mean & SD \\
\hline High (3.67-5.0) & & \\
\cline { 1 - 1 } $\begin{array}{c}\text { Moderate (2.34- } \\
\text { 3.66) }\end{array}$ & \multirow{2}{*}{2.913} & 0.300 \\
\cline { 1 - 1 } Low (1-2.33) & & \\
\hline
\end{tabular}

Table $4 \mathrm{~b}$ showed moderate level of attitude with the overall mean 2.913. The results portrayed the desirable of respondents in gaining more information about GST from authorities to avoid the lacking on knowledge. From the result, the respondents admit the rose price of agriculture farm input from GST taxation. Despite on that, they still had to coop with it to sustain their farm performance from incompetency. This is compatible to Venkatesh (2014) who claimed that expansion and wise in use of agricultural inputs is most crucial for refining agriculture productivity [15]. 


\subsection{Level of Behavior in Response to GST Implementation}

Table 5a represented respondents' behavior in response to GST implementation. The statements "Although the GST resulted in increased input prices, I'm still working hard to develop my farming activities." shows the highest mean 4.28. Meanwhile statement "Although the GST resulted in increased input prices, I still use a number the rate of input items at the same way" showed the lowest mean 3.70 .

Table 5a: Respondents' Behavior in Response to GST $(n=400)$

\begin{tabular}{|c|c|c|c|c|}
\hline No & Behavior on GST & Level & Mean & SD \\
\hline 1 & $\begin{array}{c}\text { Although the GST resulted in increased input } \\
\text { prices, I still use a number the rate of input } \\
\text { items at the same way. }\end{array}$ & High & 3.70 & 1.245 \\
\hline 2 & $\begin{array}{c}\text { Although the GST resulted in increased input } \\
\text { prices, I will still try to increase my income. }\end{array}$ & High & 4.25 & 0.725 \\
\hline 3 & $\begin{array}{c}\text { Although the GST resulted in increased input } \\
\text { prices, I'm still working hard to develop my } \\
\text { farming activities. }\end{array}$ & High & 4.28 & 0.744 \\
\hline 4 & $\begin{array}{c}\text { Although the GST resulted in increased input } \\
\text { prices, I will still continue my farming } \\
\text { activities. }\end{array}$ & High & 4.27 & 0.674 \\
\hline 5 & $\begin{array}{c}\text { Although the GST resulted in increased input } \\
\text { prices, I would not quit my farming activities. }\end{array}$ & High & 4.25 & 0.714 \\
\hline & Total average mean & 4.016 & \\
\hline
\end{tabular}

Score: 1 = strongly disagree; 2 = disagree 3 = Neutral; 4 = Agree $; 5=$ Strongly Agree

Table 5b: Behavior Perception Level $(n=400)$

\begin{tabular}{|c|c|c|}
\hline Level & Mean & SD \\
\hline High (3.67-5.0) & & \\
\cline { 1 - 1 } $\begin{array}{c}\text { Moderate (2.34- } \\
\text { 3.66) }\end{array}$ & \multirow{2}{*}{2.818} & 0.406 \\
\cline { 1 - 1 } Low (1-2.33) & & \\
\hline
\end{tabular}


Table $5 \mathrm{~b}$ showed moderate level of behavior with the overall mean 2.818. Even though the level of behavior shows a moderate score, there is a need for further strengthen. The respondents indicate that they are aware of price burden on their input but still struggling to survive in their farming activities and maintain their productivity. Hence, assessing their level of knowledge and attitude will assist relatable agencies to make a further ado to lessen their burdens.

\section{Conclusion}

This study gives a better view on the level of knowledge on GST, attitude and behavior in response to GST implementation. The results show that the farmers' level of knowledge on GST is moderate. Farmers' attitudes and behavior in response to GST implementation also shows moderate results. By assessing their level of knowledge attitude and behavior, these indicate the requirement of relatable agencies in understanding the readiness of community including farmers towards any tax system levied. In this study, it shows that there is necessary to be strengthened to increase productivity through adequate tax information transferring, appropriate extension services in providing efficient training and financial management. Agriculture extension services, Royal Malaysian Customs Department (RMCD) and Malaysia Inland Revenue Board (MIRB) have played a role in providing fundamental knowledge and information to assist farmers to survive any new tax system implementation. Thus, it also important for parties including farmers, government and non-government agencies to unitedly involve, ensuring the survival and sustainability of any scales farmers in agriculture sector.

\section{REFERENCES}

[1] Alappatt, M. (2015). Forthcoming Procedure of Goods and Service Tax (GST ) in, 2 (December 2014), 210-213.R. Caves, Multinational Enterprise and Economic Analysis, Cambridge University Press, Cambridge, 1982. (book style)

[2] Ayob A. M. (1978). The Agricultural Development: Economics, Policy and Empirical Evidence. Kuala Lumpur: Dewan Bahasa dan Pustaka.

[3] DOSM (Department of Statistics Malaysia). (2015). Malaysia Economic Performance Second Quarter 2018. Retrieved January, 2019, from https://www.dosm.gov.my/v1/index.php?r=column/cthemeByCat\&cat=100\&bul id=U0oyN StDWTh6R29rN2kwZzdxcStnQT09\&menu_id=TE5CRUZCblh4ZTZMODZIbmk2aWRR QT09

[4] DOSM (Department of Statistics Malaysia). (2017). Current Population Estimates Malaysia. Retrieved January 2019, from https://www.dosm.gov.my/v1/index.php?r=column/cthemeByCat\&cat=155\&bul id=c1pqT nFjb29HSnNYNUpiTmNWZHArdz09\&menu_id=L0pheU43NWJWRWVSZklWdzQ4TlhU $\underline{\mathrm{UT} 09}$

[5] ETP (Economic Transformation Program). 2014. Aroadmap for Malaysia:Chapter 15: Agriculture.. Retrieved from: http://etp.pemandu.gov.my/upload/etp_handbook_chapter _15_agriculture.pdf

[6] Fatt, C. K., \& Ling, L. M. (2006). Towards Goods and Services Tax in Malaysia: A Preliminary Study. Global Business \& Economics Anthology, 1(December), 75-86. 
[7] Husin, F., \& Abdullah, H. (2012). The role of FELDA and KESEDAR in the development of land in the district of Gua Musang: a comparison the socio-economic level of the settlers. Sustainable Agriculture Research, 1(2), 285-291.

[8] Imam, M., Sugeng, H. U., \&Yuli, S. (2015). The Role of Taxation Education on Taxation Knowledge and Its Effect on Tax Fairness as well as Tax Compliance on Handicraft SMEs Sectors in Indonesia. International Journal of Financial Research, 6 (4), 161-169.

[9] Jaffer, S. (2006). Islamic Retail Banking and Finance: Global Challenges and Opportunities. London: Euromoney Books.

[10] Khan, M.H. (2000). Agricultural taxation in developing countries: a survey of issues and policy. Agricultural Economics, 24, 315-328.

[11] Meinzen-Dick, R., Johnson, N., Quisumbing, A., Njuki, J., Behrman, J., Rubin, D., Peterman, A., \& Waitanji, E. (2011). Gender, Assets, and Agricultural Development Programs: A Conceptual Framework. International Food Policy Research Institute, Washington DC, (CAPRi Working Paper 99).

[12] Nurlis. \& Islamiah, K. (2015). The Effect of Taxpayer Awareness, Knowledge, Tax Penalties and Tax Authorities Services on the Tax Complience: (Survey on the Individual Taxpayer at Jabodetabek \& Bandung). Research Journal of Finance and Accounting, 24(2), 104-111.

[13] RMCD (Royal Customs Malaysian Department). (2014). GST Act 2014. Retrieved January 2019, from http://gst.customs.gov.my/en/rg/Pages/rg_bill.aspx

[14] Smith, A. (1994). The Wealth of Nations. New York, Edwin Cannan, 887-890.

[15] Venkatesh, P., \& Nithyashree, M.L. (2014). Institutional Changes in Delivery of Agricultural Inputs and Services to Farm Households in India. Agricultural Economics Research Review, 27, 85-92. DOI: 10.5958/0974-0279.2014.00010.X

[16] WTO (World Trade Organization). (2017). World Trade Statistical Review 2017. Retrieved December, 2018 , https://www.wto.org/english/res_e/statis_e/wts2017_e/wts2017_e.pdf 